\title{
PENINGKATAN HASIL BELAJAR IPA MELALUI MODEL PEMBELAJARAN KOOPERATIF TIPE THINK-TALK- WRITE PADA SISWA KELAS VIII.5 TAHUN PELAJARAN 2014/2015
}

\author{
Wiwik Sudarmiyati \\ SMP Negeri 3 Batanghari \\ Email: wiwiksudarmiyati@yahoo.co.id
}

\begin{abstract}
Abstrak
Penelitian ini bertujuan untuk meningkatkan hasil belajar fisika serta aktivitas siswa kelas VIII SMP Negeri 3 Batanghari. Bentuk penelitian ini adalah penelitian tindakan kelas. Sampel penelitan siswa kelas VIII.5 dengan jumlah 30 siswa. Penelitian dilakukan dua siklus. Setiap siklus terdiri dari empat tahap yaitu perencanaan, pelaksanaan, pengamatan, dan refleksi yang dilakukan dua kali pertemuan. Dari hasil penelitian, rata-rata menunjukan bahwa model pembelajaran Think-Talk-write dapat meningkatkan persentase aktivitas siswa dari siklus I sebesar $55 \%$ dan siklus II sebesar $69,41 \%$ sehingga berada pada rentang skor tinggi. Pembelajaran dengan strategi Think-Talkwrite juga dapat meningkatkan hasil belajar dengan ketuntasan belajar pada siklus I sebesar 53,33\% dan siklus II sebesar 90\%. Dapat disimpulkan bahwa dengan menggunakan model pembelajaran ThinkTalk-Write dapat meningkatkan hasil belajar siswa pada materi tekanan.
\end{abstract}

Kata kunci: Think-Talk-Write, hasil belajar

\section{PENDAHULUAN}

Kegiatan Belajar Mengajar (KBM) merupakan kegiatan paling utama dalam usaha peningkatan mutu pendidikan di Indonesia. Hal ini disebabkan dengan KBM tujuan pendidikan akan tercapai, yaitu berupa perubahan perilaku yang terjadi pada siswa. Undang-undang
Sistem Pendidikan Nasional No. 20 tahun 2003 pasal 3 mengemukakan tujuan pendidikan nasional sebagai berikut:

Pendidikan nasional bertujuan untuk berkembangnya potensi peserta didik agar menjadi manusia yang beriman, bertaqwa kepada Tuhan Yang Maha Esa, berakhlak mulia, sehat, berilmu, cakap, kreatif, 
mandiri, dan menjadi warga Negara yang demokratis serta bertanggung jawab.

Beberapa unsur yang terikat dan saling menunjang satu dengan yang lain dalam mencapai tujuan pembelajaran yaitu: (1) Subjek yang dibimbing atau siswa, (2) Orang yang membibing atau guru, (3) Interaksi antara guru dan siswa (Interaksi Endukatif), (4) Tujuan Pendidikan, (5) Materi Pendidikan, (6) Alat dan Metode, (7) Lingkungan Pendidikan.

Dari uraian tersebut, dapat disimpulkan bahwa dalam pembelajaran terdapat dua posisi subjek, yaitu guru dan siswa. Guru mempunyai posisi sebagai pendidik atau orang yang membimbing dan siswa adalah peserta didik atau subjek yang dibimbing. Menurut Hamzah B. Uno (2007:15), guru merupakan suatu profesi yang berarti suatu jabatan yang memerlukan keahlian khusus sebagai guru dan tidak bisa dilakukan oleh sembarang orang di luar bidang pendidikan. Hal ini berarti adalah orang dewasa yang secara sadar bertanggung jawab dalam mendidik, mengajar dan membibing peserta didik dan memiliki kemampuan merancang program pembelajaran serta mampu menata dan mengelola kelas agar peserta didik dapat belajar dan pada akhirnya dapat mencapai tingkat kedewasaan sebagai akhir proses pendidikan. Dengan demikian guru menjadi salah satu faktor yang menentukan keberhasilan dalam kegiatan belajar mengajar.

Kenyatannya dalam kegiatan pembelajaran sehari-hari di SMP Negeri 3 Batanghari dalam ruangan kelas nampak bahwa masih terdapat siswa yang belum bisa belajar dengan fokus. Memang ada sebagian siswa yang benar-benar memperhatikan dan mengikuti kegiatan pembelajaran dengan fokus, tetapi ternyata juga masih banyak yang tidak fokus dan tidak serius memperhatikan penjelasan guru dalam proses pembelajaran. Hal ini mungkin disebabkan oleh strategi, metode pembelajaran maupun gaya guru yang digunakan tidak disenangi dan menarik bagi siswa. Salah satunya adalah kegiatan pembelajaran yang berlangsung satu arah, yaitu penyampaian informasi dari guru ke siswa, namun aktivitas siswa belum memuaskan. Misalnya masih sedikit 
yang bertanya kepada guru jika belum paham dengan materi yang disampaikan.

Hal ini mungkin disebabkan siswa masih merasa takut untuk mengutarakan pertanyaan atau pendapat, dan mungkin siswa merasa bingung mengenai apa yang akan ditanyakan. Siswa biasanya lebih leluasa untuk mengutarakan pendapatnya kepada teman atau siswa yang lain.

IPA merupakan mata pelajaran yang diajarkan siswa mulai dari sekolah tingkat dasar sampai perguruan tinggi. Melalui fisika siswa diharapkan siswa mempunyai bekal untuk mampu menguasai kemampuan berpikir logis analistis, sistematis, kritis, kreatif serta kemampuan bekerjasama. Dari prasurvei yang dilakukan di kelas VIII.5 SMP Negeri 3 Batanghari didapat informasi, yaitu hasil prasurvei mengenai hasil belajar fisika, di mana datanya akan disajikan pada tabel 1. Dari tabel 1 tersebut dapat dilihat bahwa dari 28 siswa, 15 siswa tidak mencapai ketuntasan(tidak tercapai) pada materi ini siswa mengalami kesulitan dalam menghubungkan gaya, tekanan dan luas permukaan.

Penggunaan media pembelajaran juga akan sangat membantu kegiatan pembelajaran terutama dalam mata pelajaran fisika.

Penelitian ini bertujuan untuk mendeskripsikan peningkatan kemampuan hasil belajar IPA materi fisika siswa VIII.5 SMP Negeri 3 Batanghari Tahun Pelajaran $2014 / 2015$.

Tabel 1. Nilai Ulangan Harian pada materi Tekanan kelas VIII.5 SMP Negeri 3 Batanghari Tahun Pelajaran 2013/2014.

\begin{tabular}{ccccc}
\hline No & Nilai & Jumlah siswa & kategori & Persentase \\
\hline 1 & $\geq 75$ & 13 & Tercapai & $46,4 \%$ \\
2 & $<75$ & 15 & Tidak tercapai & $53,57 \%$ \\
\hline \multicolumn{2}{c}{ Jumlah } & 28 & & $100 \%$
\end{tabular}

Sumber data: Daftar Nilai Fisika Kelas VIII.5 Semester Genap Tahun Pelajaran 2013/2014 
Think artinya berpikir (kamus Inggris-Indonesia). Dalam KBBI berpikir artinya menggunakan akal budi untuk mempertimbangkan dan memutuskan sesuatu. Menurut Sardiman (2006:20) mengatakan bahwa "Berfikir adalah aktivitas mental untuk dapat merumuskan pengertian, menyintesis dan menarik kesimpulan”.

Berdasarkan pengertian-pengertian di atas, berpikir (think) merupakan kegiatan mental yang dilakukan untuk mengambil keputusan misalnya merumuskan pengertian, menyintesis, dan menarik kesimpulan setelah melalui proses mempertimbangkan. Talk artinya berbicara (kamus IngrisIndonesia). Sedangkan dalam KBBI bicara artinya pertimbangan, pikiran, pendapat. Write (kamus IngrisIndonesia). Dalam KBBI menulis adalah membuat huruf (angka dsb) dengan pena (pensil, kapur dsb).

Sehingga strategi Think-TalkWrite merupakan perencanaan dan tindakan yang cermat mengenai kegiatan pembelajaran yaitu melalui kegiatan berpikir (think), berbicara/berdiskusi, bertukar pendapat (talk) dan menulis hasil diskusi (write) agar kompetensi yang diharapkan tercapai.

Mengajar adalah suatu kejadian mengatur dan membimbing siswa sehingga terjadi proses belajar. Dalam proses belajar, siswa menjadi subyek utama dalam kegiatan belajar, maka guru dituntut untuk membuat rancangan pembelajaran yang menuntut siswa untuk melakukan aktivitas belajar. Menurut Sardiman (dalam Nurchayati, 2007:21) pada prinsipnya "Belajar adalah berbuat. Tidak ada belajar jika tidak ada aktivitas. Itulah sebabnya aktivitas merupakan prinsip atau asas yang sangat penting di dalam interaksi belajar-mengajar". Montessori (dalam Nurchayati, 2007:12) menegaskan bahwa anak-anak mempunyai tenaga untuk berkembang sendiri, membentuk sendiri. Guru sebagai pendidik hanya akan berperan untuk membimbing, mengamati, dan mendampingi anak didik dalam perkembangannya. Oleh karena itu dalam kegiatan belajar-mengajar yang lebih banyak melakukan aktivitas adalah peserta didik.

$\begin{array}{ccc}\text { Sejalan } & \text { dengan } & \text { pedapat } \\ \text { Montessori, } & \text { Rousseu } & \text { (dalam }\end{array}$


Wiwik Sudarmiyati - Peningkatan Hasil Belajar ...

Nurchayati, 2007:12) juga garis besar membaginya menjadi tiga beranggapan "Segala ranah, yakni ranah kognitif, ranah pengetahuan harus diperoleh melalui afektif, dan ranah psikomotorik. pengamatan sendiri, pengalaman Ranah kognitif berkenaan dengan sendiri, penyelidikan sendiri dengan berkerja sendiri, dengan fasilitas yang diciptakan sendiri”.

Prinsip- prinsip aktivitas dalam belajar dapat dilihat berdasarkan dua pandangan, yaitu pandangan ilmu jiwa lama dan pandangan ilmu jiwa modern. Menurut ilmu jiwa lama aktivitas dalam belajar didominasi oleh guru, dan siswa bersifat pasif. Sedangkan menurut pandangan ilmu jiwa modern beranggapan bahwa aktivitas dalam belajar didominasi oleh siswa.

Hasil belajar siswa tidak hanya dipengaruhi oleh proses pembelajaran tetapi ada beberapa faktor intern dari siswa tersebut atau faktor yang berasal dari dalam diri siswa. Sehingga penilaian yang harus dilakukan pun tidak hanya mencakup kemampuan penguasaan materi saja tetapi juga dari sikap dan keterampilan. Dalam sistem pendidikan nasional rumusan tujuan pendidikan, baik tujuan kurikuler maupun tujuan instruksional secara hasil belajar atau penguasaan materi yang telah diberikan. Ranah afektif berkenaan dengan sikap atau respon yang diberikan siswa setelah mendapatkan materi yang diberikan. Kemudian keterampilan siswa dalam mengaplikasikan materi yang telah didapat pun dapat menjadi penilaian yang dilihat dari praktikum yang dilakukan dalam melengkapi kegiatan pembelajaran di kelas.

Ketiga ranah tersebut menjadi objek penelitian hasil belajar. Kenyataan di lapangan saat ini hanya ranah kognitiflah yang banyak dinilai oleh para guru di sekolah karena berkaitan dengan kemampuan para siswa dalam menguasai isi bahan pengajaran.

\section{METODE}

Desain atau metode penelitian ini menggunakan pola penelitian tindakan kelas (Classroom Action research)

Waktu penelitian dijadwalkan dimulai pada tanggal 2 Maret s.d 18 
Maret 2015. Siklus I dilaksanakan tanggal 2 s.d 11 Maret 2015 dan siklus II dilaksanakan tanggal 16 dan 18 Maret 2015

Tempat Penelitian Tindakan Kelas ini dilaksanakan di SMP Negeri 3 Batanghari. Perlakuan ini dilakukan saat pembelajaran IPA, diberikan pada siswa kelas VIII.5, sebanyak 30 siswa yang terdiri 16 siswa laki-laki, dan 14 siswa perempuan. Penentuan kelas VIII.5 sebagai tempat penelitian karena pada kelas ini memiliki karakteristik yang dirasakan guru perlu dipebaiki dan di tingkatkan.

Dalam penelitian ini ada 2 (dua) variabael yaitu (1) model pembelajaran, dan (2) hasil belajar IPA materi fisika pada pokok materi Tekanan.
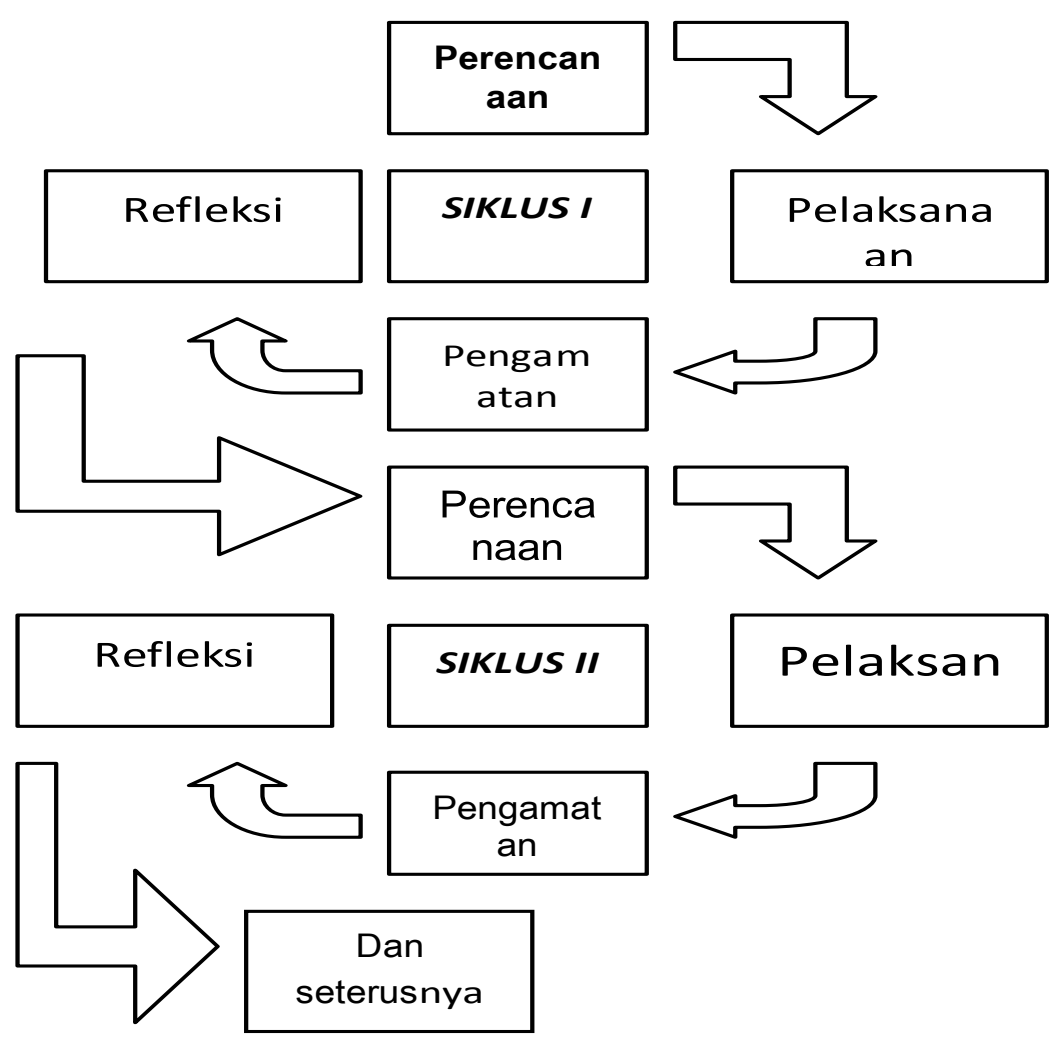

Gambar 1. Spiral Penelitian Tindakan Kelas (Arikunto, 2007:16)

Penelitian tindakan kelas dimulai pembelajaran. Masalah tersebut dengan adanya masalah yang berupa masalah yang berhubungan dirasakan sendiri oleh guru dalam dengan proses dan hasil belajar siswa 
yang tidak sesuai dengan harapan guru atau hal-hal lain yang berkaitan dengan perilaku mengajar guru dan perilaku belajar siswa. Langkah menemukan masalah dilanjutkan dengan menganalisis dan merumuskan masalah, kemudian merencanakan penelitian tindakan kelas dalam bentuk tindakan perbaikan, mengamati, dan melakukan refleksi. Keempat langkah utama dalam penelitian tindakan kelas yaitu merencanakan, melakukan tindakan perbaikan, mengamati, dan refleksi merupakan satu siklus dan dalam penelitian tindakan kelas, siklus selalu berulang. Pada pelaksanaan penelitian tindakan kelas ini dilakukan dalam 2 siklus.

Untuk memperoleh data-data yang diperlukan dalam penelitian ini, maka akan digunakan beberapa teknik pengumpulan data. Teknik yang digunakan dalam pengumpulan data dalam penelitian ini adalah sebagai berikut:

\section{Observasi}

Dimana dilakukan pengama-tan terhadap aktivitas siswa dalam proses pembelajaran, dengan meng-gunakan instrument yang telah disediakan, dengan indikatornya yaitu bertanya, mengeluarkan pendapat, berdiskusi, mendengarkan diskusi dalam kelompok, me-ngerjakan latihn dan memperhatikan penjelasan.

2. Tes

Data hasi belajar siswa diperoleh dari tes yang dilakukan oleh siswa. Tes yang dilakukan yaitu secara tertulis dengan memberikan tes objektif sebanyak 15 (lima belas) soal pada siklus I, dan 15 (lima belas) soal pada siklus II. Tes tersebut dilakukan pada akhir kegaiatan pembelajaran IPA. Tes tersebut digunakan untuk mengukur tingkat keberhasilan siswa, di mana dikatakan berhasil apabila mencapai kriteria ketuntasan minimal (KKM), di mana KKMnya 75.

\section{HASIL DAN PEMBAHASAN}

Berdasarkan data hasil penelitian dan analisis data, maka diperoleh gambaran tentang bagaimana pembelajaran dengan menggunakan metode TTW dalam meningkatkan aktivitas dan hasil belajar siswa pada materi tekanan. Berdasarkan hasil observasi yang telah dilakukan, aktivitas belajar siswa mengalami peningkatan dari siklus I sampai 
siklus II selama proses pembelajaran dengan menggunakan metode TTW (Think, Talk and Write). Data peningkatan aktivitas belajar siswa seperti dijelaskan tersebut terdapat pada tabel 2.

Tabel 2. Data Peningkatan Aktivitas Belajar Siswa dari Siklus I sampai Siklus II

\begin{tabular}{|c|c|c|c|c|c|}
\hline \multirow{2}{*}{ No } & \multirow{2}{*}{ Jenis Aktivitas } & \multicolumn{2}{|c|}{ Persentase } & \multirow{2}{*}{ Peningkatan } & \multirow{2}{*}{ ket } \\
\hline & & Siklus I & Siklus II & & \\
\hline 1 & Bertanya & $64,17 \%$ & $77,92 \%$ & $13,75 \%$ & Tercapai \\
\hline 2 & Mengeluarkan pendapat & $48,33 \%$ & $69,17 \%$ & $20,84 \%$ & Tercapai \\
\hline 3 & Berdiskusi & $59,58 \%$ & $72,91 \%$ & $13,33 \%$ & Tercapai \\
\hline 4 & $\begin{array}{l}\text { Memperhatikan diskusi } \\
\text { dalam kelompoknya }\end{array}$ & $47,50 \%$ & $59,16 \%$ & $11,66 \%$ & Tercapai \\
\hline 5 & Mengerjakan latihan & $47,33 \%$ & $64,17 \%$ & $16,84 \%$ & Tercapai \\
\hline 6 & $\begin{array}{l}\text { Memperhatikan penjelasan } \\
\text { guru }\end{array}$ & $63,17 \%$ & $73,18 \%$ & $10,01 \%$ & Tercapai \\
\hline & Rata-rata & $55 \%$ & $69,41 \%$ & & \\
\hline
\end{tabular}

Berdasarkan tabel 2 dapat dilihat bahwa aktivitas yang di amati dalam penelitian dengan menggunakan metode TTW telah mengalami peningkatan jumlah skor aktivitas belajar siswa dalam melakukan tiap aktivitas belajar dan diakhiri siklus aktivitas belajar siswa yang diamati telah mencapai persentase target skor siswa yang diinginkan sebagai indikator keberhasilan tindakan. a. Bertanya

Aktivitas belajar siswa yang diamati pada penelitian ini salah satunya adalah bertanya. Dimana pada aktivitas ini siswa keterlibatan siswa dalam suatu proses pembelajaran dan diskusi. Pada aktivitas bertanya ini siswa akan berinteraksi dengan anggota kelompoknya dalam berdiskusi menyelesaikan soal-soal dan 
pemahaman materi yang sedang dibahas. Berdasarkan penelitian ini data yang didapat pada siklus I adalah 64,17\%. Hasil pada siklus I ini menunjukkan sudah tercapainya target skor yang diharapkan dari siswa sebagai indikator ketercapaian tindakan. Pada siklus II pun aktivitas belajar siswa mencapai $77,92 \%$. Hal ini menunjukkan bahwa pada aktivitas bertanya pada siklus I sampai siklus II mengalami peningkatan. Dimana peningkatannya sebesar $13,75 \%$.

b. Mengeluarkan Pendapat

Mengeluarkan pendapat adalah salah satu aktivitas yang diamati dalam penelitian ini. Pada aktivitas ini, siswa dituntut untuk dapat menyampaikan pendapatnya atau pun menyampaikan hasil diskusi dari kelompoknya kepada anggota kelompok lain. Mengeluarkan pendapat ini merupakan cara berkomunikasi dan bekerjasama dalam kelompok. Presentase skor aktivitas mengeluarkan pendapat adalah sebesar $48,33 \%$ pada siklus I. Dimana target pencapaian pada aktivitas ini adalah 50\%. Pada siklus I ini, perlu diperhatikan kembali karena belum pencapai skor target. Pada siklus I siswa masih banyak yang kurang aktif dalam jalannya diskusi. Konsentrasi siswa belum bisa difokuskan pada jalannya diskusi. Hanya beberapa siswa yang aktif dalam diskusi yang dilakukan.

Sedangkan pada siklus II, aktivitas mengeluarkan pendapat siswa mencapai skor $69,17 \%$ dimana mengalami peningkatan sebesar 20,84\% dari siklus I. Pada siklus II dilakukan refleksi dari siklus I dimana siswa diberi evaluasi dalam menjalankan diskusi harus turut andil dan aktif dalam jalannya diskusi. Sehingga pada siklus II, diskusi sudah mengalami peningkatan aktivitas mengeluarkan pendapat dari para anggota masing-masing kelompok. Saling bekerjasama dalam menyelesaikan soal yang diberikan dan saling menanggapo pendapat teman satu kelompoknya.

c. Berdiskusi

Aktivitas belajar berupa berdiskusi yang dimaksudkan adalah pada saat siswa diberikan materi dan beberapa soal, mereka harus menyelesaikannya dalam berkelompok. Dimana ketika suatu tugas itu dilakukan 
berkelompok maka harus ada jalannya diskusi. Bukan hanya aktif aktivitas berupa diskusi untuk bertanya dan mengeluarkan pendapat, menyatukan pendapat setiap anggota kelompok yang satu dengan yang lain.

Berdasarkan tabel 2 dapat diketahui bahwa aktivitas berdiskusi ini pada siklus I belum mencapai target skor yang ditentukan. Hal itu terjadi karena pada proses jalannya diskusi siswa masih banyak yang bermain-main. Tidak semua ikut serta dalam proses diskusi berlangsung. Sebagian malah mengganggu temantemannya yang sedang berdiskusi menyelesaikan soal yang diberikan oleh guru. Pada siklus I, skor siswa yang didapat adalah sebesar 59,58\%.

Setelah dilakukan refleksi pada siklus I diharapkan siswa akan mulai aktif pada pembelajaran di siklus II. Berdasarkan data hasil pengamatan, pada siklus II aktivitas berdiskusi siswa mengalami peningkatan sebesar $13,33 \%$ atau dengan kata lain pada siklus II aktivitas siswa berdiskusi mendapat skor $72,91 \%$.

d. Memperhatikan Diskusi dalam Kelompoknya

Salah satu aktivitas belajar siswa yang diamati adalah memperhatikan tetapi menghargai pendapat anggota kelompok lain merupakan salah satu aktivitas belajar siswa. Siswa tidak hanya dituntut aktif dalam menyampaikan pendapatnya, tetapi juga perhatiaannya dalam berdiskusi, menanggapi pendapat anggota kelompok yang lain atau pun menyimak jalannya diskusi yang sedang berlangsung.

Berdasarkan data hasil pengamatan yang ada pada tabel 2, pada siklus I aktivitas ini mencapai skor 47,50\%. Dimana skor target ketuntasan tindakan pada aktivitas ini adalah $50 \%$, sehingga perlu dilakukan refleksi dan perbaikan pada siklus berikutnya. Pada siklus II, penggunaan metode TTW (Think, Talk and Write) memberikan peningkatan aktivitas belajar siswa memperhatikan diskusi dalam kelompoknya. Pada siklus II ini, didapatkan skor siswa pada aktivitas ini adalah sebesar 59,16\%. Hal ini menunjukkan bahwa terjadi peningkatan aktivitas memperhatikan diskusi dalam kelompok sebesar $11,66 \%$. 
e. Mengerjakan Latihan

Penggunaan metode TTW (Think, Talk and Write) menuntut siswa berkerjasama dalam kelompok. Pada metode ini, salah satu cara menjalankan diskusi adalah dengan memberikan soal-soal untuk diselesaikan pada setiap kelompok. Soal-soal ini diharapkan akan menjadi latihan dalam memperdalam materi dengan cara berdiskusi dengan teman sejawat.

Aktivitas mengerjakan latihan ini pada siklus I belum berjalan dengan baik, dimana hanya beberapa siswa yang aktif pada setiap kelompok dan anggota yang lain hanya menyalin kembali jawaban yang sudah didapatkan. Ini membuat jalannya diskusi belum efektif dan skor ketercapaian pada aktivitas ini belum mencapai target 50\%. Pada siklus I didapatkan skor $47,33 \%$. Setelah dilakukan refleksi pada siklus I, hasil pengamatan yang diperoleh pada siklus II mengalami peningkatan sebesar $16,84 \%$ atau dengan kata lain pada siklus II aktivitas mengerjakan latihan mendapat skor $64,17 \%$.

\section{f. Memperhatikan Penjelasan Guru}

Salah satu aktivitas belajar siswa adalah memperhatikan penjelasan guru. Pada awal pertemuan guru memberikan penjelasan materi. Siswa diharapkan tidak hanya sibuk bermain-main, mengobrol dengan teman atau sebagainya. Konsentrasi memperhatikan penjelasan guru merupakan salah satu aktivitas yang penting dimiliki siswa. Pada siklus I aktivitas ini $63,17 \%$, dimana hasil ini telah mencapai target ketercapaian tindakan. Sedangkan pada siklus II didapatkan skor $73,18 \%$. Hal ini menunjukkan peningkatan sebesar $10,01 \%$.

Selain aktivitas siswa, hasil belajar juga termasuk variabel dalam penelitian ini. Berdasarkan hasil tes yang dilakukan, hasil belajar siswa pada siklus I dan siklus II mengalami peningkatan. Peningkatan hasil belajar ditunjukkan oleh peningkatan jumlah siswa yang telah mencapai KKM.

Berdasarkan tabel 3 data peningkatan hasil belajar siswa di atas, dapat dilihat bahwa persentase siswa yang mencapai KKM mengalami peningkatan dari pra PTK ke siklus II sebesar 36,67\%. Pada 
Wiwik Sudarmiyati - Peningkatan Hasil Belajar ...

siklus I persentase siswa yang mencapai KKM sebesar $10 \%$. mencapai KKM sebesar 53,33\% dan Persentase siswa yang mencapai persentase siswa yang tidak mencapai KKM pada siklus II telah mencapai KKM sebesar 46,67\%. Persentase target keberhasilan penelitian yaitu siswa yang tuntas belajar pada siklus I pada akhir siklusnya minimal $60 \%$ belum mencapai target keberhasilan dari jumlah siswa mencapai KKM penelitian yaitu pada akhir siklusnya yang telah ditetapkan. Peningkatan minimal $60 \%$ dari jumlah siswa persentase ini disebabkan mencapai KKM yang telah pembelajaran yang dilakukan dengan ditetapkan. Pada siklus II persentase menggunakan metode TTW, dapat siswa yang mencapai KKM sebesar meningkatkan hasil belajar siswa. $90 \%$ dan persentase siswa yang tidak

Tabel 3. Data Peningkatan Hasil Belajar Siswa

\begin{tabular}{cccccc}
\hline No & Nilai & Kategori & Siklus I & Siklus II & $\begin{array}{c}\text { Peningkatan } \\
\text { dari PRA } \\
\text { PTK- siklus } \\
\text { II }\end{array}$ \\
\hline 1 & $\geq 75$ & Tercapai & $53,33 \%$ & $90 \%$ & $36,67 \%$ \\
2 & $<75$ & $\begin{array}{l}\text { Tidak } \\
\text { Tercapai }\end{array}$ & $46,67 \%$ & $10 \%$ & - \\
\hline
\end{tabular}

\section{PENUTUP}

\section{Kesimpulan}

Pembelajaran dengan model Problem Based Instruction dapat meningkatkan kemampuan berpikir kritis mahasiswa. Diperoleh hasil rata-rata kemampuan berpikir kritis mahasiswa pada siklus I 66,87 \% dan siklus II 80,19\% dengan peningkatan sebesar $13,32 \%$. Nilai rata-rata kemampuan berpikir kritis mahasiswa termasuk dalam kategori sangat kritis.

\section{Saran}

Untuk peneliti selanjutnya jika akan menggunakan model pembelajaran PBI harus menyusun rencana pembelajaran yang sistematis 
disertai Lembar Kerja Siswa agar mempermudah dalam pembelajaran.

Alokasi waktu juga diperhatikan agar tidak kekurangan waktu dalam pelaksanaan pembelajaran.

\section{DAFTAR PUSTAKA}

Al-Tabany, Trianto Ibnu Badar. 2014. Mendesain Model Pembelajaran Inovatif, Progresif, dan Kontekstual. Jakarta: Prenamedia Group.

Amarila, Raula Samsul. 2014. Pengembangan alat evaluasi kemampuan berpikir kritis siswa pada pembelajaran IPA terpadu model webbed tema lingkungan Unnes Science Education Journal ISSN 22526617.

Dwijananti. 2010. Pengembangan

Kemampuan Berpikir Kritis Mahasiswa Melalui Pembelajaran Problem Based Instruction Pada Mata Kuliah Fisika Lingkungan. Jurnal Pendidikan Fisika Indonesia 6 (2010) 108-114.

Hidayah, Nur. 2013. Efektivitas Model Pembelajaran Problem Based Instruction (PBI) terhadap hasil belajar siswa SMAN 1 Pemalang materi kelarutan dan hasil kali kelarutan. Skripsi, Jurusan Kimia, Fakultas Matematika dan Ilmu Pengetahuan Alam, Universitas Negeri Semarang.

Huda, Miftahul. 2015. Model-model Pengajaran dan Pembelajaran. Yogyakarta: Pustaka Pelajar.
Johnson, Elanie. 2009. Contextual Teaching \& Learning. Bandung: Mizan Learning Center (MLC).

Kurniawati. 2014. Pengaruh Pembelajaran Inkuiri Terbimbing Integrasi Peer Instruction Terhadap Penguasaan Konsep Dan Kemampuan Berpikir Kritis Siswa. Jurnal Pendidikan Fisika Indonesia 10 Universitas Negeri Semarang.

Nurhadi. 2004. Kurikulum 2004. Jakarta: Grasindo.

Tafsir, Ahmad. 2012. Filsafat Ilmu. Bandung: Remaja Rosdakarya.

Warso, Agus Wasisto Dwi Doso. 2013. Publikasi Ilmiah Penelitian Tindakan Kelas. Yogyakarta: Graha Cendekia. 